\title{
Preliminary Evaluation of the Possible Occurrence of Pesticides in Groundwater Contaminated with Nitrates-A Case Study from Southern Poland
}

\author{
Kinga Ślósarczyk *(D) and Andrzej Jarosław Witkowski
}

Citation: Ślósarczyk, K.; Witkowski, A.J. Preliminary Evaluation of the Possible Occurrence of Pesticides in Groundwater Contaminated with Nitrates-A Case Study from Southern Poland. Water 2021, 13, 3091. https://doi.org/10.3390/w13213091

Academic Editors: Francesco Sdao and Filomena Canora

Received: 3 October 2021

Accepted: 29 October 2021

Published: 3 November 2021

Publisher's Note: MDPI stays neutral with regard to jurisdictional claims in published maps and institutional affiliations.

Copyright: (C) 2021 by the authors. Licensee MDPI, Basel, Switzerland. This article is an open access article distributed under the terms and conditions of the Creative Commons Attribution (CC BY) license (https:// creativecommons.org/licenses/by/ $4.0 /)$.
Institute of Earth Sciences, Faculty of Natural Sciences, University of Silesia in Katowice, 60 Będzińska St., 41-200 Sosnowiec, Poland; andrzej.witkowski@us.edu.pl

* Correspondence: kinga.slosarczyk@us.edu.pl

Abstract: This paper addresses groundwater pollution and the potential presence of pesticides within the catchment areas of two reservoirs that are sources of drinking water. The two reservoirs are Goczałkowice and Kozłowa Góra, both in Southern Poland. Agricultural and rural areas dominate both catchments. Archival data showed local groundwater contamination with nitrates. This indicated the possible presence of pesticides in shallow groundwater. In total, 13 groundwater samples from shallow sandy aquifers were collected. All the samples were tested for the presence of 35 organophosphate pesticides and 28 organochlorine pesticides. Additionally, in order to determine the current groundwater conditions, physicochemical parameters were measured in the field, and water samples were subjected to analysis of their chemical composition (incl. the determination of nitrates). The research outcomes showed that pesticides were not detected above the detection limits in any of the samples. Due to variations in the persistence and degradation rates of pesticides, the occurrence of these substances in the groundwater environment and the possibility of their migration to aquifers should not be completely excluded. Natural processes and factors (e.g., sorption, biodegradation, hydrolysis and redox conditions) may gradually reduce the pesticide concentrations in groundwater. The chemical analyses revealed high concentrations of nitrates in the groundwater. This suggests the possible influence of agriculture and fertilizer application on groundwater quality; however, a proportion of $\mathrm{NO}_{3}{ }^{-}$ions may be connected with improper sewage management within the two catchments. The absence of pesticides in groundwater impacted by agriculture may result from processes occurring in the aquifer and the rapid degradation of these compounds due to photolysis and prevailing weather conditions. In the vicinity of dwellings, nitrates also originate from domestic wastewater. Thus, the occurrence of pesticides in groundwater contaminated with $\mathrm{NO}_{3}$ cannot always be expected.

Keywords: pesticides; emerging contaminants; nitrates; agriculture; groundwater quality

\section{Introduction}

Pesticides are chemicals that are widely used all over the world as plant protection products, which allow plant growth to be controlled and pests to be repelled. These substances are applied in agriculture since they significantly improve crop yields, deter pests such as insects, and kill weeds. The use of pesticides in high doses may contribute to contamination of the water environment, since chemicals may be leached from soils and migrate to shallow aquifers [1-7]. Pesticides and their metabolites have the potential for bioaccumulation and toxicity, and there are concerns regarding the effect of the drinking of contaminated water on human health [8-10]. Therefore, in some countries, pesticides in groundwater have been included in monitoring programs, e.g., in Spain [11], Ireland [4] and New Zealand [12].

Unfortunately, pesticide determination is a costly exercise, and is far more expensive than the determination of nitrates, which are the predominant form of inorganic nitrogen 
in groundwater within agricultural areas. Therefore, to minimize costs connected with groundwater quality assessments, there have been attempts to link increased concentrations of nitrates in groundwater to the presence of pesticides, especially in cases of domestic wells $[13,14]$. One example is a monitoring study conducted in Minnesota, USA [15], which revealed that high concentrations of nitrates are related to the presence of pesticide residues in shallow aquifers. It was reported that in groundwater with the highest amount of $\mathrm{NO}_{3}$, the probability of pesticide detection was $89 \%$, whereas the total pesticide concentrations reached up to $50 \mu \mathrm{g} / \mathrm{L}$. According to this study, both the detection frequency and the observed pesticide concentrations increased with the increasing nitrate concentration. Similar correlations between nitrates and pesticides in groundwater were also found in other studies conducted by Maanen et al. [16], Kraft et al. [17], Baroudi et al. [18] and Close and Humphries [12], in which the highest concentrations of nitrates in sampled water were accompanied by pesticides. Since groundwater within agricultural areas is often contaminated with $\mathrm{NO}_{3}$ and linked with agricultural activities, the co-occurrence of nitrates and pesticides in such aquifers seems to be highly probable.

Groundwater within rural areas is often enriched in nitrates [19-21]. The application of fertilizers and manure is a widespread practice; however, agricultural activity is not the only factor responsible for elevated concentrations of $\mathrm{NO}_{3}$. Another important source of nitrates in such areas is domestic wastewater [22]. THis applies primarily to unsewered areas, where nitrogen compounds may migrate from leaking septic tanks to an aquifer $[23,24]$. Several pollution sources may affect the groundwater chemical composition, and thus concentrations of some components are higher. In the case of mixed land use and the presence of potential pollution sources other than arable lands, nitrate concentrations and the occurrence of pesticide in groundwater are less likely to correlate.

In Poland, intensive farming practices were introduced at the beginning of the 1970s. Since then, the use of fertilizers as well as agricultural chemicals has increased. Not only has this led to groundwater being polluted with nitrates in rural areas, but also to the possibility of pesticides being present in shallow aquifers $[17,25,26]$. In the past, the quantity of pesticides applied in Poland for agricultural purposes was $0.6-0.8 \mathrm{~kg} / \mathrm{ha}$ (expressed as active substances) [27]. Over the last decades, the average pesticide application has increased (up to $2.2 \mathrm{~kg} / \mathrm{ha}$ in 2017), although pesticide use in Poland is lower in comparison to other European countries (e.g., Italy— $6.1 \mathrm{~kg} / \mathrm{ha}$, Germany-4.0 kg/ha, France-3.6 kg/ha). Nevertheless, in Poland a clear upward trend has been observed for pesticide application (the relative change for the period 1990-2017 was $+500 \%$ ), in contrast to Western Europe as a whole (the relative change was $-10 \%$ ) [28]. Moreover, the sale of plant protection products (herbicides) has also increased [29]. Thus, the migration of pesticides from surface to groundwater may still be expected. It is noteworthy that recent research confirmed that pesticides may still occur locally in the groundwater of Poland [30,31]. In spite of this, the monitoring of pesticides in groundwater bodies is not mandatory in this country [32].

In order to assess the groundwater contamination with pesticides and their correlation with nitrate concentrations, two areas dominated by agriculture were selected, the catchment areas of two reservoirs located in the Silesian Voivodeship, Poland: Goczałkowice and Kozłowa Góra. Previous investigations revealed increased nitrate concentrations in groundwater in both areas [33,34]. In these areas, pesticide determination for the reservoirs (Goczałkowice and Kozłowa Góra) and inflowing rivers (Vistula and Brynica) was included in studies on the status of surface water bodies [35]. To date, there has been no research on the occurrence of pesticide in shallow aquifers within these two catchments. Since there are many reports on the co-occurrence of nitrates and pesticides in groundwater within rural areas, the authors decided to test this premise in the two catchments. In the case of pesticides, two of the most common groups were taken into account: organophosphate and organochlorine pesticides. 


\section{Materials and Methods}

The study areas comprise the catchments of two water reservoirs: Goczałkowice and Kozłowa Góra (Figure 1). In the past, groundwater quality monitoring was conducted in the shallow aquifers for the following scientific projects: ZiZoZap in the Goczałkowice catchment [36] and PROLINE-CE in the Kozłowa Gora catchment [37]. However, the determination of pesticides was not included in the groundwater monitoring. There are 22 piezometers and 35 private wells in the monitoring network within the Goczałkowice catchment and 24 private wells within the Kozłowa Góra catchment. The representativeness of the monitoring points varies depending on the land use in their vicinity.
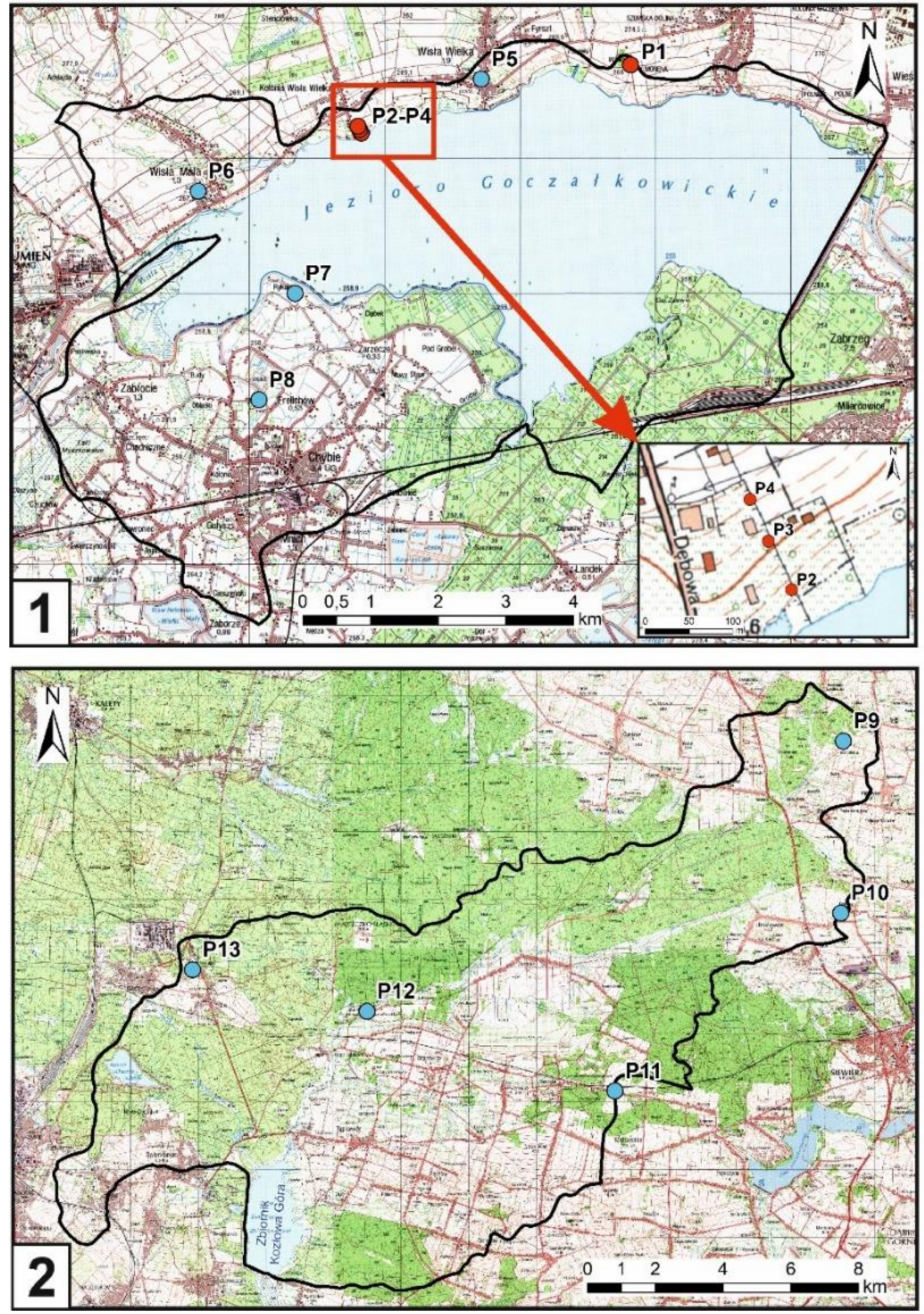

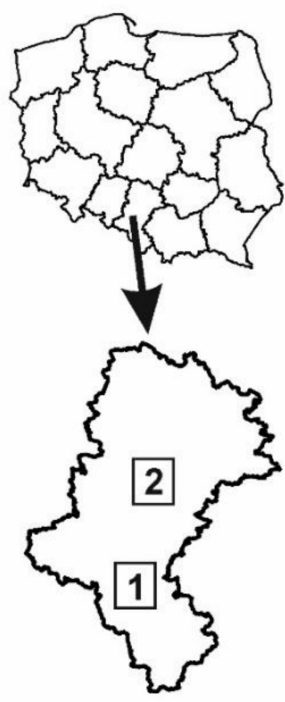

Reservoirs' catchment areas

1 Goczałkowice

2 Kozłowa Góra

\section{Sampling points \\ P1 piezometers \\ P10 wells \\ borders of the study areas}

Figure 1. Location of sampling points (based on [38]).

The Goczałkowice catchment area is $38.4 \mathrm{~km}^{2}$, of which $21.8 \mathrm{~km}^{2}(52.7 \%)$ is agricultural, especially in the northern and southwestern regions. The remaining area of the catchment includes forests $\left(9.5 \mathrm{~km}^{2} ; 24.7 \%\right)$, residential areas $\left(7.2 \mathrm{~km}^{2} ; 18.6 \%\right)$ and wetlands $\left(1.5 \mathrm{~km}^{2}\right.$; $4.0 \%)$. The Kozłowa Góra catchment area is $188.5 \mathrm{~km}^{2}$, and $77.2 \mathrm{~km}^{2}(41.0 \%)$ is occupied by crops, mainly in central, eastern and southern parts of the catchment. The other parts of the catchment are covered by forests $\left(90.3 \mathrm{~km}^{2} ; 47.8 \%\right)$, residential areas $\left(20.8 \mathrm{~km}^{2} ; 11.1 \%\right)$ and mining areas $\left(0.1 \mathrm{~km}^{2} ; 0.1 \%\right)$. In both catchments, agricultural areas constitute a significant part of land use (Figure 2). Moreover, there are no industrial areas, and in residential areas there are predominantly dispersed buildings and farmhouses [39]. In general, the sewage network is poorly developed. Apart from the northern part of the Goczałkowice catchment and the central part of the Kozłowa Góra catchment, wastewater is directed to 
septic tanks or discharged directly to watercourses. Therefore, in both catchments, apart from agriculture, the quality of groundwater may be impacted by residential areas with improper sewage management (e.g., leaky septic tanks). In this study, there was an attempt to sample groundwater in the vicinity of agricultural areas, but since wells are usually located near dwellings, at some sampling points the combined effect of both pollution sources could be observed.

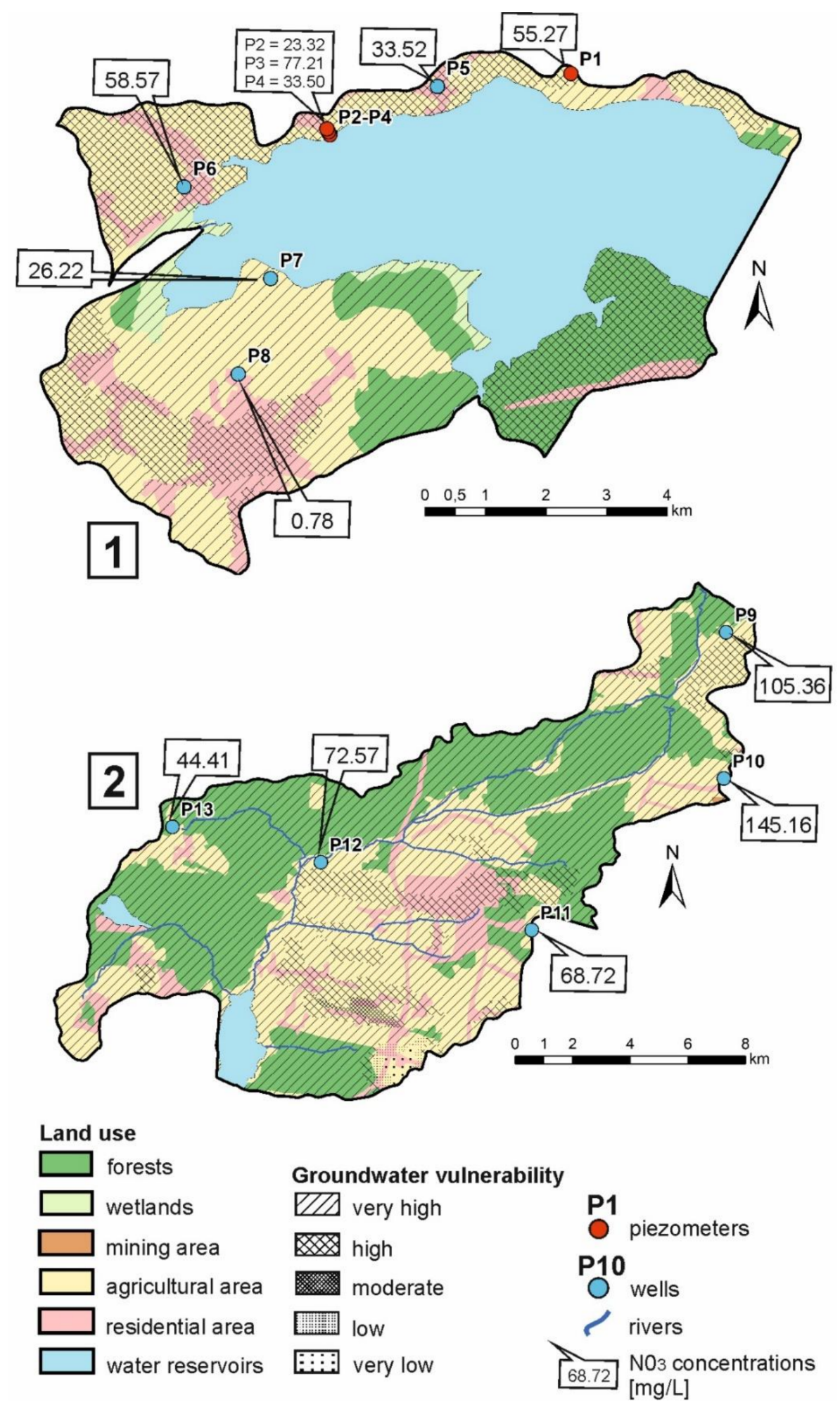

Figure 2. Land use and groundwater vulnerability in the study areas, based on [39-42]. 
During a field campaign in August 2019, 13 groundwater samples were collected within two study areas: eight samples in the catchment of the Goczałkowice reservoir and five samples in the catchment of the Kozłowa Góra reservoir (Figure 1). Samples were taken from four piezometers and nine private wells, the depth of which varied from $3.25 \mathrm{~m}$ to $30 \mathrm{~m}$. The piezometers are situated to the north of the Goczałkowice reservoir catchment and belong to the monitoring network created for the ZiZoZap project —an integrated system supporting the management and protection of water reservoirs $[33,36]$. The details of all sampling points are presented in Table 1.

Table 1. Characteristics of sampling points.

\begin{tabular}{|c|c|c|c|c|c|c|c|}
\hline $\begin{array}{l}\text { Sampling } \\
\text { Point }\end{array}$ & $\begin{array}{l}\text { Type of } \\
\text { Well }^{1}\end{array}$ & $\begin{array}{l}\text { Surface } \\
\text { Elevation } \\
\text { (m a.s.l.) }\end{array}$ & $\begin{array}{l}\text { Well Depth } \\
\text { (m) }\end{array}$ & $\begin{array}{l}\text { Water Table } \\
\text { Elevation } \\
\text { (m a.s.l.) }\end{array}$ & $\begin{array}{l}\text { Water Table } \\
\text { Depth (m) }\end{array}$ & $\begin{array}{l}\text { Land Use } \\
\text { Type }^{2}\end{array}$ & Details on Potential Pollution Sources \\
\hline \multicolumn{8}{|c|}{ The catchment area NO. 1-Goczałkowice } \\
\hline $\mathrm{P} 1$ & $\mathrm{P}$ & 266.6 & 6.8 & 262.7 & 3.9 & A & Immediate surroundings of arable lands \\
\hline $\mathrm{P} 2$ & $\mathrm{P}$ & 257.1 & 7.0 & 256.7 & 0.4 & $\mathrm{~A} / \mathrm{R}$ & $\begin{array}{l}100 \mathrm{~m} \text { from arable lands; } 250 \mathrm{~m} \\
\text { from dwellings }\end{array}$ \\
\hline P3 & $\mathrm{P}$ & 260.0 & 7.0 & 256.1 & 3.9 & $\mathrm{~A} / \mathrm{R}$ & $\begin{array}{l}100 \mathrm{~m} \text { from arable lands; } 250 \mathrm{~m} \\
\text { from dwellings }\end{array}$ \\
\hline $\mathrm{P} 4$ & $\mathrm{P}$ & 262.1 & 8.3 & 256.8 & 5.3 & $\mathrm{~A} / \mathrm{R}$ & $\begin{array}{l}100 \mathrm{~m} \text { from arable lands; } 250 \mathrm{~m} \\
\text { from dwellings }\end{array}$ \\
\hline P5 & DW & 268.5 & 30.0 & 257.9 & 10.6 & $\mathrm{~A} / \mathrm{R}$ & $\begin{array}{l}50 \mathrm{~m} \text { from arable lands; } 200 \mathrm{~m} \\
\text { from dwellings }\end{array}$ \\
\hline P6 & DW & 266.9 & 8.3 & 259.3 & 7.6 & $\mathrm{~A} / \mathrm{R}$ & $\begin{array}{l}\text { Immediate surroundings of arable lands; } \\
250 \mathrm{~m} \text { from dwellings }\end{array}$ \\
\hline P7 & DW & 256.4 & 3.8 & 253.8 & 2.6 & A & Immediate surroundings of arable lands \\
\hline P8 & DW & 258.8 & 4.7 & 256.2 & 2.7 & $\mathrm{~A} / \mathrm{R}$ & $\begin{array}{l}50 \mathrm{~m} \text { from arable lands; } 150 \mathrm{~m} \\
\text { from dwellings }\end{array}$ \\
\hline \multicolumn{8}{|c|}{ The catchment area NO. 2-Kozłowa Góra } \\
\hline P9 & DW & 341.6 & 3.3 & 339.0 & 2.7 & $\mathrm{~A} / \mathrm{F}$ & $\begin{array}{l}\text { Immediate surroundings of arable lands; } \\
200 \mathrm{~m} \text { from forests }\end{array}$ \\
\hline P10 & DW & 336.3 & 5.3 & 333.5 & 2.9 & $\mathrm{~A} / \mathrm{R}$ & $\begin{array}{l}50 \text { from arable lands; } 200 \mathrm{~m} \\
\text { from dwellings }\end{array}$ \\
\hline P11 & DW & 309.7 & 4.1 & 307.2 & 2.6 & $\mathrm{~A} / \mathrm{R}$ & $\begin{array}{l}100 \mathrm{~m} \text { from arable lands; } 400 \mathrm{~m} \\
\text { from dwellings }\end{array}$ \\
\hline $\mathrm{P} 12$ & DW & 286.3 & 5.3 & 282.2 & 4.1 & $\mathrm{~A} / \mathrm{F}$ & $\begin{array}{l}\text { Immediate surroundings of arable lands; } \\
\qquad 300 \mathrm{~m} \text { from forests }\end{array}$ \\
\hline P13 & DW & 300.2 & 4.7 & 297.3 & 2.9 & $\mathrm{~A} / \mathrm{R}$ & $\begin{array}{l}200 \mathrm{~m} \text { from arable lands; } 250 \mathrm{~m} \\
\text { from dwellings }\end{array}$ \\
\hline
\end{tabular}

${ }^{1} \mathrm{P}$ - piezometer; DW—domestic well. ${ }^{2} \mathrm{~A}$-agricultural area; $\mathrm{R}$-residential area; $\mathrm{F}$-forests.

Groundwater samples were taken from shallow sandy aquifers which are recharged directly through rainfall infiltration. Both in Goczałkowice and Kozłowa Góra catchment areas, aquifer thickness is variable, and the water table level is usually several meters deep, but locally it reaches up to $15 \mathrm{~m}[33,34,43,44]$. Generally, these are unconfined aquifers, and in some parts of the catchments they are only covered with thin loamy deposits (e.g., the northern part of the Goczałkowice catchment area, where sampled piezometers are located). Apart from a considerable area devoted to the cultivation of agricultural products, another factor favoring groundwater pollution is groundwater vulnerability due to poorly isolated aquifers against pollution originating from the surface. Within the catchments under investigation, groundwater vulnerability is characterized as very high or high in almost the entire area, with the approximate travel time of pollutants to groundwater estimated at $<5$ years and $5-25$ years, respectively [40-42,45]. Despite this, groundwater from the water-bearing horizons is often abstracted by private wells for domestic purposes. 
The selection of sampling points was based on the location (proximity to agricultural areas), as well as on the results of archival chemical analyses of groundwater, i.e., choosing sampling sites with high concentrations of nitrates that may suggest a possible effect of applied fertilizers and manure on groundwater $[33,34]$. In addition to domestic wells, groundwater from piezometers in the northern part of the Goczałkowice catchment was also sampled. At this site, samples were taken from three observation wells, where screens are placed in the same aquifer and along the groundwater flow path [33]. This sampling allowed the lateral migration of contaminants to be tracked in order to determine the difference in concentrations within one sandy aquifer.

As the nearest surroundings of the sampled wells were arable lands, the most probable pollution source was agriculture (Table 1). However, some points were located close to residential areas without a wastewater collection system. Within these areas, leaking septic tanks and domestic sewage may also have influenced groundwater quality in terms of nitrate concentrations.

The main objective of this study was to determine the occurrence of pesticide residues in shallow aquifers contaminated with nitrates, but since natural conditions and water chemistry affect pesticide persistence, basic measurements of water properties and chemical composition analysis were also carried out. During the fieldwork, physicochemical parameters (temperature, $\mathrm{pH}$, redox potential, conductivity, $\mathrm{O}_{2}$ concentrations) were measured using portable equipment: ELMETRON meters CP-401, CC-411 and CP-315, as well as the WTW Oxi 315i oxygen meter.

Samples were gathered in 100-mL polyethylene vials. Fully filled vials were stored at $+4{ }^{\circ} \mathrm{C}$ and transported to the laboratory. Each sample was filtered through a $0.45-\mu \mathrm{m}$ cellulose membrane filter. The analysis of groundwater chemical composition was performed at the Laboratory of Water Analysis at the Faculty of Natural Sciences of the University of Silesia, using ion chromatography (Metrohm 850 Professional IC). All groundwater samples were analyzed for major ions $\left(\mathrm{SO}_{4}{ }^{2-}, \mathrm{Cl}^{-}, \mathrm{Ca}^{2+}, \mathrm{Mg}^{2+}, \mathrm{Na}^{+}, \mathrm{K}^{+}\right)$, as well as inorganic nitrogen compounds $\left(\mathrm{NO}_{3}{ }^{-}, \mathrm{NO}_{2}{ }^{-}, \mathrm{NH}_{4}{ }^{+}\right)$. In the case of $\mathrm{HCO}_{3}{ }^{-}$, its concentration was calculated on the basis of alkalinity, determined by titration with $\mathrm{HCl}$.

Groundwater samples for pesticide determinations were taken as separate samples. Analyses of pesticide residues were performed at the JARS S.A. accredited laboratory. For these analyses, each water sample was collected in a $1 \mathrm{~L}$ amber glass bottle, filling approximately $90 \%$ of its volume. The samples were stored in a refrigerator and transported to the laboratory within a few hours. The pesticide analyses included 35 organophosphate compounds and 28 organochlorine compounds, including pesticide metabolites and substances which are currently prohibited. The determination of organophosphate pesticides in water was performed using gas chromatography (Agilent 7890 coupled with a mass spectrometer) after dichloromethane extraction. In the case of organochlorine pesticides, the method of gas chromatography (Perkin Elmer 590 combined with Electron Capture Detector) after liquid-liquid extraction was applied. The analyses of organophosphate and organochlorine pesticide residues were performed in accordance with the standards PN-EN 12918:2004 and PN-EN ISO 6468:2002, respectively [46,47].

The studied compounds, along with the limits of quantification (LOQ) for the methods, are listed in Table 2. 
Table 2. The list of analyzed pesticides.

\begin{tabular}{|c|c|c|c|c|c|c|c|c|}
\hline \multicolumn{9}{|c|}{ Organophosphate pesticides } \\
\hline Compound & USE $^{1}$ & $\mathrm{LOQ}^{2}$ & Compound & USE $^{1}$ & $\mathrm{LOQ}^{2}$ & Compound & USE $^{1}$ & $\mathrm{LOQ}^{2}$ \\
\hline Dichlorvos & I & $<0.050$ & Cypermethrin & I & $<0.050$ & Pirimiphos-ethyl & I. A & $<0.050$ \\
\hline Diazinon & I & $<0.10$ & Deltamethrin & I & $<0.050$ & Mecarbam & I. A & $<0.050$ \\
\hline Parathion-ethyl & $\mathrm{I}, \mathrm{A}$ & $<0.050$ & Fluopicolide & F & $<0.050$ & Methidathion & I & $<0.050$ \\
\hline Parathion-methyl & I & $<0.050$ & Captan & $\mathrm{F}$ & $<0.050$ & Fensulfothion & I & $<0.050$ \\
\hline Malathion & I & $<0.050$ & Mefenpyr-diethyl & $\mathrm{H}$ & $<0.050$ & Azinphos-methyl & I & $<0.050$ \\
\hline Chlorpyrifos-ethyl & I & $<0.030$ & Oxyfluorfen & $\mathrm{H}$ & $<0.050$ & Phosalone & I. A & $<0.050$ \\
\hline Chlorpyrifos-methyl & I & $<0.030$ & Trifloxystrobin & F & $<0.050$ & Isoproturon & $\mathrm{H}$ & $<0.050$ \\
\hline Chlorpyrifos & I & $<0.030$ & $\lambda$-cyhalothrin & I & $<0.050$ & Fenvalerate & I & $<0.050$ \\
\hline Chlorfenvinfos & $\mathrm{I}, \mathrm{A}$ & $<0.050$ & $\beta$-cyfluthrin & I & $<0.050$ & Fenpropathrin & I & $<0.050$ \\
\hline Fenitrothion & I & $<0.050$ & Bifenthrin & I & $<0.050$ & Permethrin & I & $<0.050$ \\
\hline Malaoxon & I & $<0.050$ & Procymidone & $\mathrm{F}$ & $<0.050$ & Metribuzin & $\mathrm{H}$ & $<0.050$ \\
\hline Pyrazophos & I, F & $<0.050$ & Ethoprophos & I. $\mathrm{N}$ & $<0.050$ & Diflufenican & $\mathrm{H}$ & $<0.050$ \\
\hline Triazofos & $\mathrm{I}, \mathrm{A}, \mathrm{N}$ & $<0.050$ & Pirimiphos-methyl & I & $<0.050$ & & & \\
\hline \multicolumn{9}{|c|}{ Organochlorine pesticides } \\
\hline Compound & USE $^{1}$ & $\mathrm{LOQ}^{2}$ & Compound & USE $^{1}$ & $\mathrm{LOQ}^{2}$ & Compound & USE $^{1}$ & $\mathrm{LOQ}^{2}$ \\
\hline Aldrin & I & $<0.010$ & $\alpha-\mathrm{HCH}$ & I & $<0.010$ & Endosulfan I & I. A & $<0.010$ \\
\hline Dieldrin & I & $<0.010$ & $\beta-\mathrm{HCH}$ & I & $<0.010$ & Endosulfan II & I. A & $<0.010$ \\
\hline Endrin & $\mathrm{I}, \mathrm{R}$ & $<0.010$ & $\delta-\mathrm{HCH}$ & I & $<0.010$ & Endrin aldehyde & I. $\mathrm{R}$ & $<0.010$ \\
\hline Isodrin & I & $<0.010$ & $\gamma$-HCH. lindane & I & $<0.010$ & $\begin{array}{l}\text { Methoxychlor } \\
\text { (DMDT) }\end{array}$ & I & $<0.010$ \\
\hline o.p-DDT & I & $<0.010$ & $\begin{array}{l}\text { Hexachlorocyclohexane } \\
\text { (HCH) }\end{array}$ & I & $<0.010$ & Trifluralin & $\mathrm{H}$ & $<0.010$ \\
\hline p.p-DDT & I & $<0.010$ & Total $\mathrm{HCH}$ & I & $<0.010$ & Alachlor & $\mathrm{H}$ & $<0.010$ \\
\hline o.p'-DDE & I & $<0.010$ & Heptachlor epoxide B & I & $<0.010$ & Endosulfan sulfate & I. A & $<0.010$ \\
\hline p.p.-DDE & I & $<0.010$ & Heptachlor & I & $<0.010$ & $\begin{array}{l}\text { Hexachlorobenzene } \\
\text { (HCB) }\end{array}$ & F & $<0.010$ \\
\hline o.p'-DDD & I & $<0.010$ & $\alpha$-chlordan & I & $<0.010$ & & & \\
\hline p.p'-DDD & I & $<0.010$ & $\gamma$-chlordan & I & $<0.010$ & & & \\
\hline
\end{tabular}

${ }^{1}$ I-insecticide, A-acaricide, N-nematicide, F-fungicide, H-herbicide, R-rodenticide. ${ }^{2}$ LOQ-limit of quantification, in $\mu \mathrm{g} / \mathrm{L}$.

\section{Results and Discussion}

The field measurements conducted in the Goczałkowice catchment indicated that water temperature ranged between $11.8^{\circ} \mathrm{C}(\mathrm{P} 1)$ and $17.6^{\circ} \mathrm{C}(\mathrm{P} 6)$. Groundwater $\mathrm{pH}$ ranged from slightly acidic to slightly alkaline, and the measured values were between 5 (P1) and 7.37 (P5). Electrical conductivity ranged from $213 \mu \mathrm{S} / \mathrm{cm}$ (P7) to $785 \mu \mathrm{S} / \mathrm{cm}$ (P5). The values of redox potential ranged from slightly reducing to neutral conditions (according to [26]), i.e., from $-52.5 \mathrm{mV}$ (P8) to $241.1 \mathrm{mV}$ (P1), whereas concentrations of dissolved oxygen varied from $2.31 \mathrm{mg} / \mathrm{L}$ (P3) to $12.41 \mathrm{mg} / \mathrm{L}$ (P5). As for the Kozłowa Góra area, the water temperature ranged from $15{ }^{\circ} \mathrm{C}(\mathrm{P} 10)$ to $18^{\circ} \mathrm{C}$ (P13), $\mathrm{pH}$ values from 6.21 (slightly acidic; P9) to 7.08 (neutral pH; P12), electrical conductivity from $390 \mu \mathrm{S} / \mathrm{cm}$ (P9) to $1033 \mu \mathrm{S} / \mathrm{cm}$ (P13), redox potential values indicated neutral conditions, from $105.5 \mathrm{mV}$ (P12) to $173.2 \mathrm{mV}$ (P9) and dissolved oxygen concentrations ranged from $0.89 \mathrm{mg} / \mathrm{L}$ (P11) to $4.06 \mathrm{mg} / \mathrm{L}$ (P13).

The chemical composition of groundwater in terms of major ions varied depending on the sampling area. With regard to samples taken from piezometers in the northern part of the Goczałkowice area, the dominant anion was $\mathrm{SO}_{4}{ }^{2-}$ and the dominant cation was $\mathrm{Ca}^{2+}$. In the other groundwater samples collected in this catchment, $\mathrm{HCO}_{3}{ }^{-}$was the most abundant anion. The same constituents as the dominant ions were observed in groundwater within the Kozłowa Góra area, with the exception of the P13 sampling 
point, where the main anion was $\mathrm{SO}_{4}{ }^{2-}$. In this well, distinctive groundwater chemistry was manifested by elevated concentrations of such ions as sulphates, chlorides, calcium and sodium, indicating the input of pollutants from an additional source, presumably improper wastewater management. The details on the chemical composition of the sampled groundwater with regard to the major ions are presented in Table 3 and Figure 3.

Table 3. Physico-chemical properties of groundwater samples.

\begin{tabular}{|c|c|c|c|c|c|c|c|c|c|c|c|c|c|c|c|}
\hline \multicolumn{16}{|c|}{ The catchment area NO. 1-Goczałkowice } \\
\hline \multirow{2}{*}{ Sample } & Temp. & $\mathrm{pH}$ & PEW & Eh & $\mathrm{O}_{2}$ & $\mathrm{HCO}_{3}^{-}$ & $\mathrm{SO}_{4}{ }^{2-}$ & $\mathrm{Cl}^{-}$ & $\mathrm{Ca}^{2+}$ & $\mathrm{Mg}^{2+}$ & $\mathrm{Na}^{+}$ & $\mathrm{K}^{+}$ & $\mathrm{NH}_{4}{ }^{+}$ & $\mathrm{NO}_{2}^{-}$ & $\mathrm{NO}_{3}^{-}$ \\
\hline & ${ }^{\circ} \mathrm{C}$ & - & $\mu \mathrm{S} / \mathrm{cm}$ & $\mathrm{mV}$ & $\mathrm{mg} / \mathrm{L}$ & $\mathrm{mg} / \mathrm{L}$ & $\mathrm{mg} / \mathrm{L}$ & $\mathrm{mg} / \mathrm{L}$ & $\mathrm{mg} / \mathrm{L}$ & $\mathrm{mg} / \mathrm{L}$ & $\mathrm{mg} / \mathrm{L}$ & $\mathrm{mg} / \mathrm{L}$ & $\mathrm{mg} / \mathrm{L}$ & $\mathrm{mg} / \mathrm{L}$ & $\mathrm{mg} / \mathrm{L}$ \\
\hline P1 & 13.3 & 5 & 311 & 241.1 & 6.77 & 9.20 & 48.20 & 34.75 & 32.54 & 10.34 & 8.58 & 2.05 & 0 & 0.08 & 55.27 \\
\hline P2 & 11.8 & 5.35 & 282 & 228.5 & 9.25 & 21.40 & 79.82 & 17.73 & 31.49 & 8.13 & 10.59 & 2.24 & 0 & 0.07 & 23.32 \\
\hline P3 & 11.9 & 5.47 & 658 & 235.4 & 2.31 & 33.60 & 208.94 & 37.35 & 79.88 & 18.58 & 22.37 & 14.33 & 0 & 0.29 & 77.21 \\
\hline P4 & 12.5 & 5.3 & 494 & 252.5 & 4.03 & 27.40 & 172.54 & 27.35 & 54.32 & 14.89 & 24.01 & 4.35 & 0 & 0.14 & 33.50 \\
\hline P5 & 12.9 & 7.37 & 785 & 114.2 & 12.41 & 329.50 & 147.81 & 25.34 & 120.83 & 13.92 & 37.27 & 32.99 & 1.76 & 0.30 & 33.52 \\
\hline P6 & 13.1 & 6.33 & 457 & 200.6 & 8.34 & 152.60 & 57.69 & 15.56 & 58.68 & 11.92 & 17.15 & 14.64 & 0 & 0.15 & 58.57 \\
\hline P7 & 17.6 & 6.59 & 213 & 197.2 & 4.31 & 85.40 & 11.43 & 3.25 & 22.86 & 3.23 & 3.26 & 20.16 & 0 & 0.11 & 26.22 \\
\hline P8 & 13.9 & 6.66 & 563 & -52.5 & 7.99 & 250.20 & 78.23 & 30.54 & 88.69 & 8.37 & 29.42 & 1.89 & 0.44 & 0.22 & 0.78 \\
\hline \multicolumn{16}{|c|}{ The catchment area NO. 2-Kozłowa Góra } \\
\hline \multirow{2}{*}{ Sample } & Temp. & $\mathrm{pH}$ & PEW & Eh & $\mathrm{O}_{2}$ & $\mathrm{HCO}_{3}^{-}$ & $\mathrm{SO}_{4}{ }^{2-}$ & $\mathrm{Cl}^{-}$ & $\mathrm{Ca}^{2+}$ & $\mathrm{Mg}^{2+}$ & $\mathrm{Na}^{+}$ & $\mathbf{K}^{+}$ & $\mathrm{NH}_{4}{ }^{+}$ & $\mathrm{NO}_{2}^{-}$ & $\mathrm{NO}_{3}-$ \\
\hline & ${ }^{\circ} \mathrm{C}$ & - & $\mu \mathrm{S} / \mathrm{cm}$ & $\mathrm{mV}$ & $\mathrm{mg} / \mathrm{L}$ & $\mathrm{mg} / \mathrm{L}$ & $\mathrm{mg} / \mathrm{L}$ & $\mathrm{mg} / \mathrm{L}$ & $\mathrm{mg} / \mathrm{L}$ & $\mathrm{mg} / \mathrm{L}$ & $\mathrm{mg} / \mathrm{L}$ & $\mathrm{mg} / \mathrm{L}$ & $\mathrm{mg} / \mathrm{L}$ & $\mathrm{mg} / \mathrm{L}$ & $\mathrm{mg} / \mathrm{L}$ \\
\hline P9 & 15.1 & 6.21 & 390 & 173.2 & 3.46 & 91.50 & 38.16 & 11.64 & 53.30 & 6.51 & 9.79 & 18.26 & 0 & 0.16 & 105.36 \\
\hline P10 & 15 & 7.04 & 721 & 144.2 & 4.04 & 305.10 & 43.81 & 20.87 & 131.03 & 10.67 & 11.03 & 23.53 & 0 & 0.29 & 145.16 \\
\hline P11 & 16.9 & 6.64 & 462 & 136.8 & 0.89 & 118.90 & 75.87 & 18.09 & 66.32 & 5.39 & 16.00 & 11.73 & 0 & 1.15 & 68.72 \\
\hline P12 & 13.5 & 7.08 & 434 & 105.5 & 3.98 & 106.80 & 64.18 & 21.42 & 64.81 & 7.12 & 12.40 & 10.81 & 0 & 0.23 & 72.57 \\
\hline P13 & 18 & 6.57 & 1033 & 148.7 & 4.06 & 122.00 & 409.65 & 105.21 & 154.29 & 35.56 & 63.08 & 10.33 & 0 & 0.38 & 44.41 \\
\hline
\end{tabular}

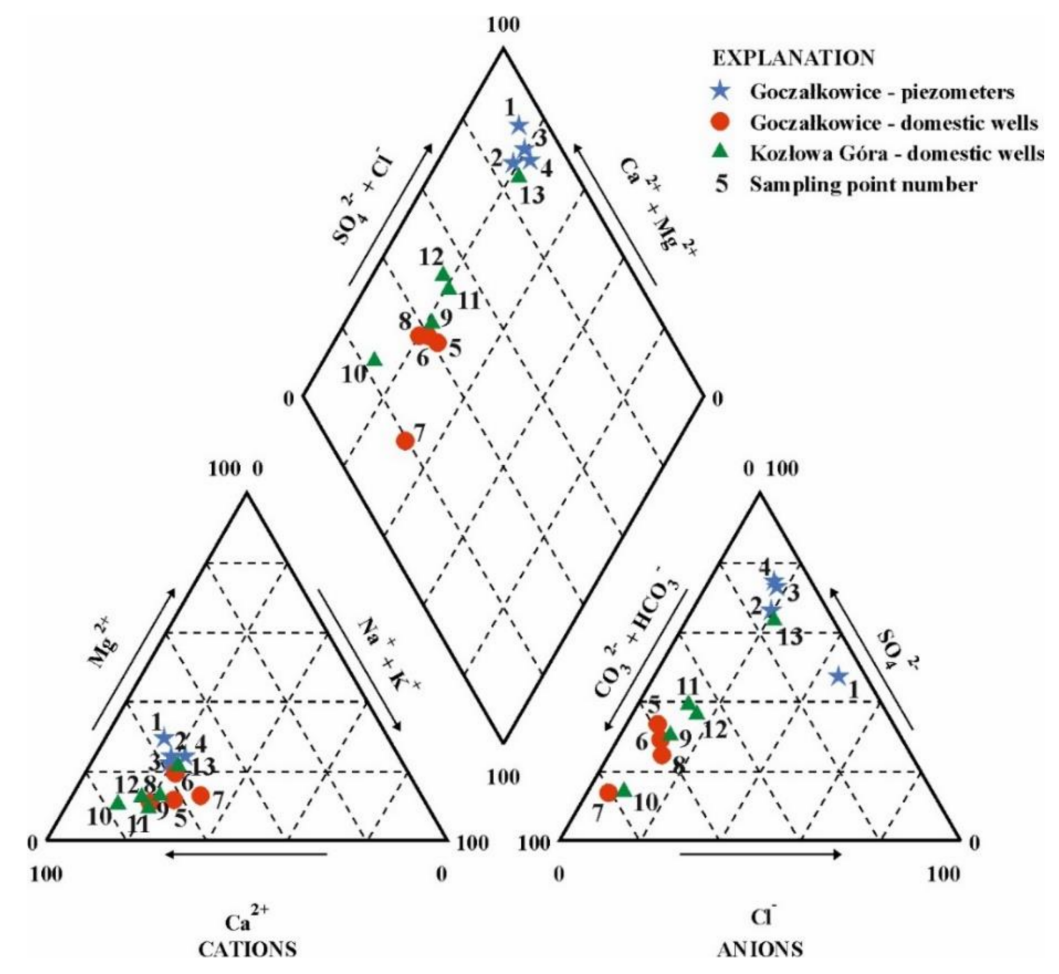

Figure 3. Piper diagram for groundwater chemical composition in the study sites.

Generally, the results of chemical analyses indicated high concentrations of nitrates, especially in groundwater within the Kozłowa Góra catchment, where $\mathrm{NO}_{3}{ }^{-}$concentra- 
tions reached up to $145.16 \mathrm{mg} / \mathrm{L}$ (P10; Table 3). In the Goczałkowice area, the highest concentration of nitrates was $77.21 \mathrm{mg} / \mathrm{L}$ (P3; Figure 2). The concentration of nitrites in the study areas was significantly lower (up to $0.30 \mathrm{mg} / \mathrm{L}$ in P5 in the Goczałkowice catchment and up to $1.15 \mathrm{mg} / \mathrm{L}$ in P11 in the Kozłowa Góra area). In two samples collected from domestic wells in the Goczałkowice area, ammonium ions were detected $(1.76 \mathrm{mg} / \mathrm{L}$ in P5 and $0.44 \mathrm{mg} / \mathrm{L}$ in P8). These results point to the different redox conditions in the Goczałkowice catchment (oxic conditions in the northern part and reducing conditions in the south) [33]. Nevertheless, slightly reducing conditions were encountered only locally, and nitrates were the most abundant of the inorganic nitrogen compounds in groundwater within the studied catchments.

Table 4 shows the hydrogeochemical types of sampled groundwater according to the classification by Szczukariew-Prikłoński [48]. In this classification, the hydrogeochemical type of natural water includes major ions $\left(\mathrm{HCO}_{3}{ }^{-}, \mathrm{SO}_{4}{ }^{2-}, \mathrm{Cl}^{-}, \mathrm{Ca}^{2+}, \mathrm{Mg}^{2+}, \mathrm{Na}^{+}\right)$which account for at least $20 \%$ of the total concentrations separately for anions and cations, in meq/L. However, there is a modified version of this classification that is applied for groundwater in which the chemistry is altered due to human impact. In the modified version, constituents other than major ions (which occur at at least 17\%) are also taken into account [48]. It is notable that in eight water samples, nitrates accounted for more than $17 \%$ of the total concentration of anions (expressed as meq/L). Such high relative nitrate concentrations in the samples (from $17 \%$ in sample P3 to $39 \%$ in sample P9) indicate the negative impact of human activity on groundwater quality. This entails changes to the hydrogeochemical types, since the $\mathrm{NO}_{3}{ }^{-}$ion appears in the formulae (Table 4).

Table 4. Hydrogeochemical types of sampled groundwater.

\begin{tabular}{|c|c|c|}
\hline \multirow{2}{*}{ Sampling Point } & \multicolumn{2}{|c|}{ Hydrogeochemical Type } \\
\hline & Szczukariew-Prikłoński & Modified Version (Incl. $\mathrm{NO}_{3}$ ) \\
\hline \multicolumn{3}{|c|}{ The catchment area NO. 1-Goczałkowice } \\
\hline P1 & $\mathrm{SO}_{4}-\mathrm{Cl}-\mathrm{Ca}-\mathrm{Mg}$ & $\mathrm{SO}_{4}-\mathrm{Cl}-\mathrm{NO}_{3}-\mathrm{Ca}-\mathrm{Mg}$ \\
\hline P2 & $\mathrm{SO}_{4}-\mathrm{Ca}-\mathrm{Mg}$ & $\mathrm{SO}_{4}-\mathrm{Ca}-\mathrm{Mg}$ \\
\hline P3 & $\mathrm{SO}_{4}-\mathrm{Ca}-\mathrm{Mg}$ & $\mathrm{SO}_{4}-\mathrm{NO}_{3}-\mathrm{Ca}-\mathrm{Mg}$ \\
\hline $\mathbf{P 4}$ & $\mathrm{SO}_{4}-\mathrm{Ca}-\mathrm{Mg}-\mathrm{Na}$ & $\mathrm{SO}_{4}-\mathrm{Ca}-\mathrm{Mg}-\mathrm{Na}$ \\
\hline P5 & $\mathrm{HCO}_{3}-\mathrm{SO}_{4}-\mathrm{Ca}$ & $\mathrm{HCO}_{3}-\mathrm{SO}_{4}-\mathrm{NO}_{3}-\mathrm{Ca}$ \\
\hline P6 & $\mathrm{HCO}_{3}-\mathrm{SO}_{4}-\mathrm{Ca}$ & $\mathrm{HCO}_{3}-\mathrm{SO}_{4}-\mathrm{Ca}$ \\
\hline P7 & $\mathrm{HCO}_{3}-\mathrm{Ca}$ & $\mathrm{HCO}_{3}-\mathrm{NO}_{3}-\mathrm{Ca}$ \\
\hline P8 & $\mathrm{HCO}_{3}-\mathrm{SO}_{4}-\mathrm{Ca}$ & $\mathrm{HCO}_{3}-\mathrm{SO}_{4}-\mathrm{Ca}$ \\
\hline \multicolumn{3}{|c|}{ The catchment area NO. 2-Kozłowa Góra } \\
\hline P9 & $\mathrm{HCO}_{3}-\mathrm{SO}_{4}-\mathrm{Ca}$ & $\mathrm{NO}_{3}-\mathrm{HCO}_{3}-\mathrm{SO}_{4}-\mathrm{Ca}$ \\
\hline P10 & $\mathrm{HCO}_{3}-\mathrm{Ca}$ & $\mathrm{HCO}_{3}-\mathrm{NO}_{3}-\mathrm{Ca}$ \\
\hline P11 & $\mathrm{HCO}_{3}-\mathrm{SO}_{4}-\mathrm{Ca}$ & $\mathrm{HCO}_{3}-\mathrm{SO}_{4}-\mathrm{NO}_{3}-\mathrm{Ca}$ \\
\hline P12 & $\mathrm{HCO}_{3}-\mathrm{SO}_{4}-\mathrm{Ca}$ & $\mathrm{HCO}_{3}-\mathrm{SO}_{4}-\mathrm{NO}_{3}-\mathrm{Ca}$ \\
\hline P13 & $\mathrm{SO}_{4}-\mathrm{Cl}-\mathrm{Ca}-\mathrm{Mg}-\mathrm{Na}$ & $\mathrm{SO}_{4}-\mathrm{Cl}-\mathrm{Ca}-\mathrm{Mg}-\mathrm{Na}$ \\
\hline
\end{tabular}

The results of the pesticide analyses revealed that in collected samples neither organophosphate nor organochlorine pesticides were detected at concentrations above the limit of quantification (LOQ) established for the applied methods. Seemingly, groundwater that was free of pesticide pollution could indicate no impact of agricultural activities on water quality in the study areas, especially since the negative results also relate to organochlorine pesticides, which are considered to be the most persistent substances $[48,49]$. However, high concentrations of $\mathrm{NO}_{3}{ }^{-}$ions were observed in both of the study catchments. 
With the exception of water from the P8 sampling point, the concentration of nitrates in all the remaining samples was significantly above the level of the natural background concentration for $\mathrm{NO}_{3}{ }^{-}$, i.e., more than $5 \mathrm{mg} \mathrm{NO}_{3}{ }^{-} / \mathrm{L}$ [26]. Moreover, in seven out of 13 samples, nitrates exceeded the limit for drinking water, i.e., $50 \mathrm{mg} \mathrm{NO}{ }^{-} / \mathrm{L}$ [50]. Such large quantities support the idea that these ions primarily originate from anthropogenic sources. In the light of land use patterns and possible pollution sources associated with human activity in the research areas, the application of fertilizers and manure on arable land seems to be responsible for the considerable input of $\mathrm{NO}_{3}{ }^{-}$to shallow aquifers. Elevated $\mathrm{NO}_{3}$ concentrations in groundwater were observed in the near vicinity of arable lands (P1, P6, P9 and P12). Within these areas, only agricultural activities lead to groundwater pollution with nitrates. In the case of the other sampling points, the exact extent of the impact of agricultural and residential areas is challenging to assess based only on nitrate concentrations and the location of sampling points. For this reason, additional studies could be applied to determine the main origin of $\mathrm{NO}_{3}$, e.g., isotopic analysis [51].

It is worth recalling that, in general, agriculture is considered to be the main pollution source of nitrates, since it accounts for $70 \%$ of the excessive amounts of $\mathrm{NO}_{3}{ }^{-}$in groundwater [27]. Nonetheless, the absence of a sewage system in some parts of the catchments may also be connected with the high concentration of nitrates. In addition, a certain amount of $\mathrm{NO}_{3}{ }^{-}$ions may be introduced to groundwater through leaking septic tanks [51]. Hence, groundwater quality may be affected by agricultural areas alone or by both agricultural and residential areas [33]. In such areas, the correlation between nitrate concentration and the occurrence of pesticide is not always apparent [14].

We did not manage to obtain detailed information on the types and quantity of pesticides used in the study areas. The absence of pesticide residues does not necessarily indicate the absolute cessation of the use of plant protection products. The results below the detection limits may indicate the low quantity of applied chemicals, which in some agricultural areas is often lower than the average pesticide application. One example is an agricultural region in Morocco, where no pesticides were detected in soil and shallow groundwater despite high nitrate concentrations. In these areas, the amount of applied pesticides did not exceed $0.5 \mathrm{~kg} / \mathrm{ha}$ [14]. However, high groundwater vulnerability within some areas (related to soil permeability and its sandy texture) favors the migration of potential contaminants to the groundwater, and the pesticides may reach the aquifer despite the low usage of chemicals [40-42,52]. Although groundwater vulnerability was assessed as being very high or high in both the studied catchments (Figure 2), the pesticides were not detected. As the soil and aquifer parameters foster the migration and occurrence of contaminants in groundwater, other factors should be considered as responsible for the absence of pesticides within these areas.

Pesticides vary in terms of their chemical structure and properties; thus, in combination with the variability of natural conditions, the persistence of these compounds in the environment also differed. In the soil and groundwater environment, pesticides undergo a range of processes, leading to a decrease in their concentration. Therefore, groundwater quality deterioration caused by intensive agricultural activities may be manifested by high concentrations of $\mathrm{NO}_{3}{ }^{-}$alone, regardless of the application of pesticides.

One of the most important processes is adsorption, which occurs on the surface of soil particles and suspended particulate matter. The sorption depends on the solubility of a particular pesticide, as well as water $\mathrm{pH}$ and chemical composition. The same factors play a crucial role in the bioaccumulation of pesticides $[26,49]$. It is noteworthy that pesticides have different sorption tendencies, which, in general, are higher in organochlorine pesticides ( $\log \mathrm{K}_{\mathrm{ow}}$ : 3.20 to 6.91$)$ in comparison with organophosphate pesticides $\left(\log \mathrm{K}_{\mathrm{ow}}\right.$ : -0.79 to 3.69) [53]. Furthermore, organophosphate pesticides are characterized by higher solubility, and they are more biodegradable. In addition, the rate of these processes, as well as the degree of hydrolysis of some pesticides, increases with increasing temperature.

Biodegradation also depends on the presence of microorganisms and proceeds more slowly in aquifers than in soil due to the less favorable living conditions for the microor- 
ganisms. Nevertheless, pesticide biodegradation is often reported as the main process that viably reduces pesticide contamination in aquifers $[5,54]$. It should also be noted that under warm and moist conditions, especially at the low depths close the root zone, microbes degrade pesticides, leading to their complete transformation to harmless molecules, such as water and $\mathrm{CO}_{2}[14,52,55]$.

Another important process that leads to a decrease in pesticide concentrations is the chemical breakdown of molecules, known as hydrolysis. This process particularly concerns organophosphate pesticides [56,57]. Hydrolysis happens rapidly in high temperatures and in alkaline water with a pH value between 8 and 9 [58]. In the case of the two catchments, groundwater was mostly slightly acidic ( $\mathrm{pH}$ values between 5 and 7.37) (Table 3). The groundwater temperature was relatively high (from $11.8^{\circ} \mathrm{C}$ to $18.0^{\circ} \mathrm{C}$ ) (Table 3); however, hydrolysis is active mainly near the soil surface since the rate of the process slows along with the decrease in temperature at greater depths $[59,60]$. Therefore, pesticides are mostly detected in shallow groundwater with lower temperatures and $\mathrm{pH}$ values [12]. Hydrolysis is a process that commonly occurs in the water environment, nevertheless, with regard to the results of physicochemical measurements, it seems to serve a diminished role in pesticide degradation within the two catchments.

Redox conditions are another important factor affecting the degradation rate of pesticides. In many cases, faster degradation and higher mobility of pesticides are observed in oxic groundwater conditions compared with anoxic conditions. In low-oxygen conditions, hydrolysis or oxidation processes are considerably slower, and thus pesticide degradation is slower as well $[54,61]$. However, even in low-oxygen conditions, the presence of nitrates in groundwater may accelerate pesticide degradation and lead to lower concentrations in anoxic conditions [62]. Groundwater conditions were mostly defined as slightly reducing and neutral in the two catchments. Despite this, pesticides were not detected in any of the water samples, and the influence of nitrates on pesticide degradation cannot be excluded.

Due to all these processes and chemical properties, pesticide residence time in the environment differs depending on particular compounds. In general, it varies from two to six months $[49,63]$. Among the pesticides, organochlorine compounds are some of the most persistent components, especially DDT, DMDT, $\gamma-\mathrm{HCH}, \mathrm{HCB}$, aldrin, dieldrin, heptachlor and isodrin, which have half-lives that exceed one year. These substances are also more likely to bioaccumulate. Although DDT and dieldrin are currently prohibited due to their high toxicity, in some areas they are still present in the aquatic environment due to their very long decay time of up to several decades. The pesticides commonly applied prior to the introduction of the ban were replaced by other chemicals, mostly by organophosphate pesticides, i.e., the pesticide group considered to be less toxic and less persistent in the water environment $[27,48,49]$. In some cases, pesticides are detected only shortly after application due to their rapid degradation and short half-lives not exceeding 2-3 weeks $[14,64]$. The groundwater within the study areas was sampled only once, in August. In the case of organophosphate compounds, the low $t_{1 / 2}$ values for the pesticides in current use indicate that the contaminants could have been degraded shortly after their application during spring or early summer. This would probably have been facilitated by the high temperatures, low precipitation and intense sunlight that favors the photolysis of pesticides before their migration to the soil and groundwater [59]. The variability of weather conditions throughout the year is relevant as it has an effect on the degradation rate of pesticides, migration feasibility and hydrogeological conditions that are firmly linked with the persistence of contaminants, their mobility and the possibility of leaching to an aquifer. With regard to a number of factors that determine the presence of pesticides in aquifers, the co-occurrence of nitrates and pesticides in groundwater cannot always be anticipated. The correlation between pesticides and nitrates may not be observed even in areas under a strong agricultural influence [65]. Moreover, nitrates in groundwater within rural areas are often of mixed origin, as $\mathrm{NO}_{3}{ }^{-}$ions are derived from agricultural activities and domestic wastewater infiltration from leaky septic tanks to the aquifer. Thus, nitrates should not be regarded as an indicator of pesticide pollution, and both 
these constituents ought to be monitored simultaneously [66]. In the case of the studied catchment, further research on a more frequent basis should be considered. This would facilitate a better understanding of the processes that are occurring and enable fluctuations or trends over time to be determined. It would also enable the calculation of the potential risk of groundwater pollution in other seasons.

\section{Conclusions}

Although the significant influence of human activity (agriculture combined with poor sewage management) on groundwater quality was manifested through elevated concentrations of nitrates (up to $145.16 \mathrm{mg} / \mathrm{L}$ ), the results of the investigation showed that pesticides were absent or nearly so. Over the last few years, both the application and sale of pesticides have increased; however, they were not detected in wells under the potential combined impact of agriculture and improper sewage management, nor in sampling points located in agricultural areas far from households and other buildings. It can be assumed that nitrates in the groundwater from sampling points P1, P7, P9 and P12 only originated from agricultural activity. In this regard, it should be concluded that groundwater contaminated with $\mathrm{NO}_{3}$ originating from agricultural sources does not necessarily indicate the presence of pesticide residues. Negative results were obtained concerning organochlorine pesticides (more persistent in the environment) as well as organophosphate compounds (with lower half-lives). Nonetheless, the absence of pesticide residues in aquifers within the studied catchments does not imply that groundwater bodies in other parts of Poland (where agricultural dominates) are also free from pollution. It is still the case that little is known about the co-occurrence of nitrates and pesticides in thr groundwater of Poland; therefore, more research should be considered to assess the possible correlations between nitrate concentrations and the presence of pesticides in aquifers.

Author Contributions: Conceptualization, K.Ś. and A.J.W.; methodology, K.Ś.; investigation, K.Ś.; resources, K.Ś. and A.J.W.; writing_-original draft preparation, K.S.; writing—review and editing, A.J.W.; visualization, K.S.; supervision, A.J.W.; funding acquisition, K.Ś. All authors have read and agreed to the published version of the manuscript.

Funding: This study was performed in the framework of the project titled "The modification of groundwater chemical composition in selected aquifers under conditions of diversified human activity with regard to emerging contaminants", financed from a grant of the Ministry of Sciences and Higher Education of Poland for conducting research by young scientists and PhD students.

Data Availability Statement: The data presented in this study are available within this article.

Acknowledgments: The authors would like to thank Piotr Siwek for his assistance during fieldwork.

Conflicts of Interest: The authors declare no conflict of interest. The funders had no role in the design of the study; in the collection, analyses, or interpretation of data; in the writing of the manuscript, or in the decision to publish the results.

\section{References}

1. Jankowska, M. Pesticides in natural water. Ochr. Śr. 1998, 68, 13-16.

2. Biziuk, M. Pesticides-Occurrence, Determination and Disposal; Wydawnictwo Naukowo-Techniczne: Warsaw, Poland, 2009; ISBN 83-2042-663-4.

3. Lindahl, A.M.L.; Bockstaller, C. An indicator of pesticide leaching risk to groundwater. Ecol. Indic. 2012, 23, 95-108. [CrossRef]

4. McManus, S.; Coxon, C.E.; Mellander, P.; Danaher, M.; Richards, K.G. Hydrogeological characteristics influencing the occurrence of pesticides and pesticide metabolites in groundwater across the Republic of Ireland. Sci. Total Environ. 2017, 601, 594-602. [CrossRef] [PubMed]

5. Lorenzo, T.D.; Cifoni, M.; Fiasca, B.; Cioccio, A.D.; Galassi, D.M.P. Ecological risk assessment of pesticide mixtures in the alluvial aquifers of central Italy: Toward more realistic scenarios for risk mitigation. Sci. Total Environ. 2018, 644, 167-172. [CrossRef]

6. Demir, A.E.A.; Dilek, F.B.; Yetis, U. A new screening index for pesticides leachability to groundwater. J. Environ. Manag. 2019, 231, 1193-1202. [CrossRef] [PubMed] 
7. Haddad, K.; Gheid, A.; Haddad, D.; Oulmi, K. Experimental and numerical study on the leaching of pesticides into the groundwater through a porous medium: Effect of transport parameters. Environ. Technol. Inno. 2019, 13, 244-256. [CrossRef]

8. Kjær, J.; Rosenbom, A.; Brüsch, W.; Juhler, R.K.; Gudmundsson, L.; Plauborg, F.; Grant, R.; Olsen, P. The Danish Pesticide Leaching Assessment Programme. Monitoring results May 1999-June 2010; Kjær, J., Ed.; Geological Survey of Denmark and Greenland: Copenhagen, Dennmark, 2011; ISBN 978-87-7871-312-4.

9. Velasco, A.; Hernández, S.; Ramírez, M.; Ortíz, I. Detection of residual organochlorine and organophosphorus pesticides in agricultural soil in Rio Verde region of San Luis Potosí, Mexico. J. Environ. Sci. Health B 2014, 49, 498-504. [CrossRef] [PubMed]

10. Rodríguez, A.G.P.; López, M.I.R.; Casillas, Á.D.; Leónc, J.A.A.; Banik, S.D. Impact of pesticides in karst groundwater. Review of recent trends in Yucatan, Mexico. Groundw. Sustain. 2018, 7, 20-29. [CrossRef]

11. Köck-Schulmeyer, M.; Ginebreda, A.; Postigo, C.; Garridob, T.; Fraile, J.; Alda, M.L.; Barceló, D. Four-year advanced monitoring program of polar pesticides in groundwater of Catalonia (NE-Spain). Sci. Total Environ. 2014, 470, 1087-1098. [CrossRef] [PubMed]

12. Close, M.E.; Humphries, B. The 2014 national survey of pesticides in groundwater in New Zealand. J. Hydrol. 2016, 55, 73-88.

13. Squillace, P.J.; Scott, J.C.; Moran, M.J.; Nolan, B.T.; Kolpin, D.W. VOCs, pesticides, nitrate, and their mixtures in groundwater used for drinking water in the United States. Environ. Sci. Technol. 2002, 36, 1923-1930. [CrossRef] [PubMed]

14. Marouane, B.; Dahchour, A.; Dousset, S.; Hajjaji, S.E. Monitoring of nitrate and pesticide pollution in Mnasra, Morocco soil and groundwater. Water Environ. Res. 2015, 87, 567-575. [CrossRef] [PubMed]

15. Minnesota Department of Agriculture, Monitoring Unit of Pesticide and Fertilizer Management Division-Analysis of the Co-occurrence of Nitrate-Nitrogen and Pesticides in Minnesota Groundwater. Available online: https://www.leg.mn.gov/docs/ 2008/ other /080926.pdf (accessed on 5 May 2021).

16. Maanen, J.M.S.V.; Vaan, M.A.J.D.; Veldstra, A.W.F.; Hendrix, W.P.A.M. Pesticides and nitrate in groundwater and rainwater in the province of Limburg in The Netherlands. Environ. Monit. Assess. 2001, 72, 95-114. [CrossRef]

17. Kraft, G.J.; Browne, B.A.; DeVita, W.M.; Mechenich, D.J. Nitrate and Pesticide Residue Penetration into a Wisconsin Central Sand Plain Aquifer; University of Wisconsin-Stevens Point: Stevens Point, Wisconsin, USA, 2004; Available online: https:/ /www.uwsp. edu/cnr-ap/watershed/documents/penetration_sandplain.pdf (accessed on 5 May 2021).

18. Baroudi, M.; Bakkour, H.; Halwani, J.; Taha, S.; El Osmani, R.; Mouneimne, A.H. Determination of pesticides, nitrates and nitrites level in groundwater of Akkar plain in Northern Lebanon. J. Appl. Sci. Res. 2012, 8, 4663-4667.

19. Yu, G.; Wang, J.; Liu, L.; Li, Y.; Zhang, Y.; Wang, S. The analysis of groundwater nitrate pollution and health risk assessment in rural areas of Yantai, China. BMC Public Health 2020, 20, 437. [CrossRef]

20. Zufiaurre, R.; Martín-Ramos, P.; Cuchí, J.A. Nitrates in groundwater of small shallow aquifers in the western side of Hoya de Huesca (NE Spain). Agronomy 2019, 10, 22. [CrossRef]

21. Suthar, S.; Bishnoi, P.; Singh, S.; Mutiyar, P.K.; Nema, A.K.; Patil, N.S. Nitrate contamination in groundwater of some rural areas of Rajasthan, India. J. Hazard. Mater. 2009, 171, 189-199. [CrossRef]

22. Balla, D.; Zichar, M.; Tóth, R.; Kiss, E.; Karancsi, G.; Mester, T. Geovisualization techniques of spatial environmental data using different visualization tools. Appl. Sci. 2020, 10, 6701. [CrossRef]

23. Mester, T.; Szabó, G.; Balla, D. Assessment of shallow groundwater purification processes after the construction of a municipal sewerage network. Water 2021, 13, 1946. [CrossRef]

24. Mester, T.; Balla, D.; Karancsi, G.; Bessenyei, E.; Szabó, G. Effects of nitrogen loading from domestic wastewater on groundwater quality. Water SA 2019, 45, 349-358. [CrossRef]

25. Burrow, K.R.; Shelton, J.L.; Dubrovsky, N.M. Occurrence of Nitrate and Pesticides in Ground Water Beneath Three Agricultural Land-Use Settings in the Eastern San Joaquin Valley, California, 1993-1995; Water-Resourses Investigations Report 97-4298; US Geological Survey: Sacramento, CA, USA, 1998.

26. Witczak, S.; Kania, J.; Kmiecik, E. Catalog of Selected Physical and Chemical Indicators of Groundwater Pollution and Methods of Their Determination; Biblioteka Monitoringu Środowiska: Warsaw, Poland, 2013; ISBN 978-83-61227-13-7.

27. Łyp, B. Civilization-Related Pollution of Groundwater in Poland; Wydawnictwo Seidel-Przywecki: Warsaw, Poland, 2019; ISBN 978-83-60956-61-8.

28. Our World in Data-Pesticides. Available online: http:/ / ourworldindata.org/pesticides (accessed on 22 June 2020).

29. Statistics Poland-Means of Production in Agriculture in the 2017/18 Farming Year. Available online: https: / stat.gov.pl/en/ topics/agriculture-forestry/agriculture/means-of-production-in-agriculture-in-the-20172018-farming-year, 6,3.html (accessed on 22 June 2020).

30. Cabalska, J.; Mikołajczyk, A.; Polak-Mazur, D.; Wołkowicz, W. Occurrence of pesticides in the measurement points of groundwater chemical status monitoring. Prz. Geol. 2015, 63, 635-638.

31. Dragon, K.; Górski, J.; Kruc', R.; Drożdżyński, D.; Grischek, T. Removal of natural organic matter and organic micropollutants during riverbank filtration in Krajkowo, Poland. Water 2018, 10, 1457. [CrossRef]

32. Regulation of the Minister of the Environment of 9 October 2019 on the Forms and Methods of Surface Water and Groundwater Bodies Monitoring. Available online: http:/ /isap.sejm.gov.pl/isap.nsf/download.xsp/WDU20190002147/O/D20192147.pdf (accessed on 5 May 2021).

33. Czekaj, J.; Jakóbczyk-Karpierz, S.; Rubin, H.; Sitek, S.; Witkowski, A.J. Identification of nitrate sources in groundwater and potential impact on drinking water reservoir (Goczałkowice reservoir, Poland). Phys. Chem. Earth 2016, 94, 35-46. [CrossRef] 
34. Czekaj, J.; Skrzypczak, M.; Siudy, A. Implementation of Best Practices for Water Protection in Pilot Actions. Partner-Specific Pilot Action Documentations; The Report of PROLINE-CE Workpackage T2 (D.T2.2.2); Interreg Central Europe PROLINE-CE. Available online: https:/ / www.interreg-central.eu/Content.Node/CE110-PROLINE-CE-T2-D.T2.2.2-9-pilot-action-reports.zip (accessed on 5 May 2021).

35. Chief Inspectorate of Environmental Protection-Status Assessment of River and Dam Reservoirs in 2017-2018. Available online: https://www.gios.gov.pl/images/dokumenty/pms/monitoring_wod/Klasyfikacja_i_ocena_stanu_RW_2017_2018x.xlsx (accessed on 22 June 2020).

36. Sołtysiak, M.; Witkowski, A.J.; Kaźmierczak, J. Hydrogeological aspects of realization of project "integrated system supporting management and protection of Dammed Reservoir (ZiZoZap)"-An example of Goczałkowice reservoir. Biul. Państwowego Inst. Geol. 2011, 445, 651-660.

37. Ulańczyk, R.; Kożuch, B. Monitoring środowiska wodnego i badania modelowe realizowane w obszarze zlewni zbiornika Kozłowa Góra. Gospod. Wodna 2020, 2, 19-22.

38. Topografic Map of Poland. Available online: https://mapy.geoportal.gov.pl/wss/service/img/guest/TOPO/MapServer/ WMSServer (accessed on 5 May 2021).

39. CLC 2018. CORINE Land Cover 2018. Available online: https:/ /land.copernicus.eu/pan-european/corine-land-cover/clc2018 (accessed on 28 October 2021).

40. Kempa, J.; Winckiewicz, A. Hydrogeological Map of Poland 1:50 000 "First Aquifer-Groundwater Vulnerability" Sheet Koziegłowy 878; Państwowy Instytut Geologiczny: Warsaw, Poland, 2010.

41. Kempa, J.; Winckiewicz, A. Hydrogeological Map of Poland 1:50 000 "First Aquifer-Groundwater Vulnerability" Sheet Wojkowice 911; Państwowy Instytut Geologiczny: Warsaw, Poland, 2010.

42. Sołtysiak, M.; Rubin, K. Hydrogeological Map of Poland 1:50 000 "First Aquifer-Groundwater Vulnerability" Sheet Pszczyna 992; Państwowy Instytut Geologiczny: Warsaw, Poland, 2013.

43. Czekaj, J.; Witkowski, A.J. Structural model of the quaternary aquifer in the area of Goczałkowice reservoir. Biul. Państwowego Inst. Geol. 2012, 451, 27-33.

44. Rodzoch, A.; Mutek, K.; Karwacka, K.; Pazio-Urbanowicz, K.; Grodzka, M.; Jeleniewicz, G. Hydrogeological Documentation Establishing the Disposable Groundwater Resources of the Biała Przemsza and Przemsza River Basins; HYDROEKO-Biuro Poszukiwań i Ochrony Wód: Warsaw, Poland, 2012.

45. Kajewski, I. Assessment of groundwater vulnerability to pollution by organic pesticides in environmental conditions of agricultural catchment. Infrastrukt. Ekol. Teren. Wiej. 2010, 8, 69-78.

46. PN EN 12918: Water Quality-Determination of Parathion, Parathion-Methyl and Some other Organophosphorus Compounds in Water by Dichloromethane Extraction and Gas Chromatographic Analysis; Polish Committee for Standardization: Warsaw, Poland, 2013.

47. PN-EN ISO 6468:2002: Water Quality_Determination of Certain Organochlorine Insecticides, Polychlorinated Biphenyls and Chlorobenzenes_-Gas Chromatographic Method after Liquid-Liquid Extraction; Swedish Standard Institution: Stockholm, Sweden, 2012.

48. Macioszczyk, A.; Dobrzyński, D. Hydrogeochemistry of an Active Groundwater Exchange Zone; Wydawnictwo Naukowe PWN: Warsaw, Poland, 2007; ISBN 978-83-01151-35-5.

49. Świderska-Bróż, M. Micropollutants and Their Removal from Natural Waters; Wydawnictwo Politechniki Wrocławskiej: Wrocław, Poland, 1993; ISBN 83-7085-046-4.

50. Regulation of the Minister of Health of 7 December 2017 on Water Quality Intended for Human Consumption. Available online: http:/ /isap.sejm.gov.pl/isap.nsf/download.xsp/WDU20170002294/O/D20172294.pdf (accessed on 5 May 2021).

51. Blarasin, M.; Cabrera, A.; Matiatos, I.; Quinodóz, F.B.; Albo, J.G.; Lutri, V.; Matteos, E.; Panarello, H. Comparative evaluation of urban versus agricultural nitrate sources and sinks in an unconfined aquifer by isotopic and multivariate analyses. Sci. Total Environ. 2020, 741, 140374. [CrossRef]

52. Buttler, T.; Martinkovic, W.; Nesheim, O.N. Factors Influencing Pesticide Movement to Ground Water; University of Florida, Institute of Food and Agricultural Sciences: Gainesville, FL, USA, 1998.

53. Affum, A.O.; Acquaah, S.O.; Osae, S.D.; Kwaansa-Ansah, E.E. Distribution and risk assessment of banned and other current-use pesticides in surface and groundwaters consumed in an agricultural catchment dominated by coca crops in the Ankobra Basin, Ghana. Sci. Total Environ. 2018, 633, 360-640. [CrossRef]

54. Fenner, K.; Canonica, S.; Wackett, L.P.; Elsner, M. Evaluating pesticide degradation in the environment: Blind spots and emerging opportunities. Science 2014, 341, 725-758. [CrossRef]

55. Sasikala, C.; Jiwal, S.; Rout, P.; Ramya, M. Biodegradation of chlorpyrifos by bacterial consortium isolated from agriculture soil. World J. Microbiol. Biotechnol. 2012, 28, 1301-1308. [CrossRef]

56. Sirotkina, M.; Lyagin, I.; Efremenko, E. Hydrolysis of organophosphorus pesticides in soil: New opportunities with ecocompatible immobilized His6-OPH. Int. Biodeterior. Biodegrad. 2012, 68, 18-23. [CrossRef]

57. Dyguda-Kazimierowicz, E.; Roszak, S.; Sokalski, A. Alkaline hydrolysis of organophosphorus pesticides: The dependence of the reaction mechanism on the incoming group conformation. J. Phys. Chem. B 2014, 118, 7277-7289. [CrossRef]

58. Fishel, F. Effects of Water $\mathrm{pH}$ on the Stability of Pesticides. Integrated Pest Management 1017:1-2. MU Extension, University of Missouri, Columbia, USA. Available online: https://extension.missouri.edu/media/wysiwyg/Extensiondata/Pub/pdf/ agguides/pests/ipm1017.pdf (accessed on 5 May 2021). 
59. Draper, W.; Wolfe, N. Abiotic Processes in the Degradation of Pesticides in Natural Waters; US Environmental Protection Agency: Washington, DC, USA, 2002.

60. Katagi, T. Abiotic hydrolysis of pesticides in the aquatic environment. Rev. Environ. Contam. Toxicol. 2002, 175, 79-261.

61. Živančev, N.; Kovačević, S.; Perović, P.; Čalenić, A.; Dimkić, M. Influence of oxic and anoxic groundwater conditions on occurrence of selected agrochemicals. Water Supply 2019, 20, 487-498. [CrossRef]

62. Papiernik, S.K.; Spalding, R.F. Atrazine, deethylatrazine, and deisopropylatrazine persistence measured in groundwater in situ under low-oxygen conditions. J. Agric. Food Chem. 1998, 46, 749-754. [CrossRef]

63. Włodarczyk-Makuła, M. Selected Organic Micropollutants in Waters and Soil; Komitet Inżynierii Środowiska PAN: Warsaw, Poland, 2013; ISBN 978-83-63714-03-1.

64. Carbo, L.; Souza, V.; Dores, E.F.G.C.; Ribeiro, M.L. Determination of pesticides multi-residues in shallow groundwater in a cotton-growing region of Mato Grosso, Brazil. J. Braz. Chem. Soc. 2008, 19, 1111-1117.

65. Mathys, W. Pesticide pollution of groundwater and drinking water by the processes of artificial groundwater enrichment or coastal filtration: Underrated sources of contamination. Zentralbl. Hyg. Umweltmed. 1994, 196, 338-359.

66. Burrow, K.R.; Stork, S.V.; Dubrovsky, N.M. Nitrate and Pesticides in Ground Water in the Eastern San Joaquin Valley, California: Occurrence and Trends; Water-Resourses Investigations Report 98-4040; US Geological Survey: Sacramento, CA, USA, 1998. 